\title{
Effect of Thrust Force and Torque Analysis on Chemically Treated Kevlar Reinforced Composites during Drilling Process
}

\author{
S. Chandrakumar, K. Periasamy, N. Sivashankar, V. Vairamani
}

\begin{abstract}
Composites applications are widely used in many areas. Due to the enhancement of various properties. Now a days kevlar composite has widely used because of various properties like tensile, compression, shear. Drilling is the majority important machining process in making assembly of components within a negligible tolerance. Drilling in kevlar composites is difficult due its extradionary mechanical properties like high toughness and hardness. Thrust force and torque are the major influences for delamination during various machining of reinforcement polymer composites. Various paramaters are considered to reduce defects like delamination and fiber crushing. It is found from various literature reviews surface modification has enhancing the intermolecular bonding strength between fiber reinforced layers. Our paper deals with affect of process parameters on thrust force with respect to torque during drilling of Kevlar composites with and without chemically treated fibers. The composite lamina is prepared for the investigation of 60/40 kevlar-polyester resin on weight basis. The chemicals are used to treat the fibers such as Dichloromethane, methanol and distilled water with specified intervals of time. Twist and core drill bits are used to make holes. Results suggested that twist drill with chemically treated fiber having minimum thrust force. Our aim to identify the minimum delamination of composites.
\end{abstract} Torque

Keywords: Delamination, Drilling, Kevlar, Thrust force,

\section{INTRODUCTION}

Reinforced polymer composites having mechanical properties like toughness, hardness, Tensile, Compression strength etc. Recently more number of research has been carried out to replacing metals into composites. Kevlar fibers are frequently used in most of the ballistic application, aerospace industry, commercial products like helmets , armours etc., Mechanical machining of reinforced polymer has challenging because identical in nature. Especially drilling is a difficult machining process because, distribution of force during machining is not even. Most of the research work has been carried in this field and found torque and twisting moment are major cause of delamination of composites. This paper mainly focuses effect of chemical treatment on torque and twisting moment to reduce delamination.

Revised Manuscript Received on February 05, 2020.

* Correspondence Author

Mr. S. Chandrakumar*, Assistant Professor/Mech. Engg., Kongunadu college of Engg. and Tech, Tamilnadu, India.

Dr. K. Periasamy, Professor and Coordinator, Mechanical Engineering, Kongunadu college of Engg. And Tech., Tamilnadu, India.

Mr. N. Sivashankar, Assistant Professor/Mech. Engg., Kongunadu college of Engg. and Tech, Tamilnadu, India.

Mr. V. Vairamani, Assistant Professor/Mech. Engg., Kongunadu college of Engg. and Tech, Tamilnadu, India.

(C) The Authors. Published by Blue Eyes Intelligence Engineering and Sciences Publication (BEIESP). This is an open access article under the CC BY-NC-ND license (http://creativecommons.org/licenses/by-nc-nd/4.0/)
Chemical treated fibers is helps to develop the improved and new surface of treated Kevlar, which is aimed to increase composites performance and the bonding strength between both martix and fiber.

Various techniques has been analyzed in the literature study, the relationship between the fiber surface (with or without treatment). The various literature study shows the microscopic and the macroscopic structure and properties of composite, including the fiber-matrix adhesion. Kevlar 49 fibers were treated successively under room temperature with 1,2-dichloroethane, methanol and distilled water and then vacuum dried.

Srinivasan et al investigated the influence of process parameters, feed rate, drill diameter, type of drill based of thrust force and torque. They conducted the experiments in vertical milling machine. Specifically drill diameters are $6,9,12 \mathrm{~mm}$ taken in to account. The results are drill diameter and feed rate are the major influence in machining[1].Bhattacharya et al investigated the machining operation on the Kevlar-reinforced polymer composites the machining operation is characterized for the poor, fuzzy surface finish with partially pulled-out and crushed fibers. Tungsten-carbide-reinforced tooling is suggested for the drilling operation on KFRP composites. In this study HSS drills are slightly modified to perform the drilling operation. Interestingly, the poor surface quality and edge damage at the entry and the exit faces of the drilled holes can be totally eliminated by the usage of liquid nitrogen and the introduction of very thin resin-rich layers on the laminate surfaces. The investigation has been carried out at both room $\backslash$ and cryogenic temperatures [2]. Shuaib et al studied the machinability condition of the Kevlar fiber reinforced composite material by using the TiN coated $135^{\circ}$ HSS split point $6 \mathrm{~mm}$ diameter drill bit. In this study he investigated on different drilling parameters like drilling thrust force, cutting force, and specific cutting energy [3]. Haijin wang et al discuss the drilling induced major delamination of composites materials, so the experiments are takes place with different drilling depths. To know the delamination in various cross sectional and radial section of hole grinding is adopted. Periodically we change the drill depth and analyzed. Finally the research investigates the hidden delamination zone and critical thrust forces of delamination are analyzed [4]. Rajamurugan et al analyzed delamination of GFRP Composites with polyester can be minimized by various parameter using Response Surface Methodology technique (Empirical relationship). The parameters are spindle speed, tool diameter ,fiber orientation and feed rate, by the study shows increase in drill diameter and feed rate delamination also increases, by the spindle speed shows the very little effect [5].
Retrieval Number: C6107029320/2020@BEIESP DOI: 10.35940/ijeat.C6107.029320 Journal Website: www.ijeat.org
Published By: \& Sciences Publication 
Tsao et al explains about the thrust force and surface roughness of the composites. Here the methods used are Taguchi and artificial neural network approaches.

Drill bit used here is candlestick, results shows feed rate and drill diameter is the major parameter to affect thrust force feed rate and spindle speed will affect the surface roughness [6]. Tsao et al analyzed most of the hole making process drilling plays a major role. Here delamination is a serious concern of composites at a bottom surface of exit in specimen. Some parameters are responsible including drill geometry, here we used core and saw drill bits. Delamination can be effectively minimized by reducing the feed rate and introducing the backup plates for improves the support. The result of drilling shows larger critical thrust force created at larger feed rate for without delamination [7]. Shyu et al describes the surface modification by the chemical treatment such as NH3 , H2O-plasma etching etc,.After the chemical treatment fiber surface were etched and fiber surface modification takes place. The composites are made by chemically treated Kevlar with epoxy, by these combination shear strength and T-peel strength of fiber are increased. If the higher concentration acids are treated with fibers results as poor, the treated fibers are shown in various images [8]. Lei et al studied the chemical treatment on kevlar fiber by using the, sodium hydride and dimethylsulfoxide as a chemical solution, to enhance the surface of Kevlar fiber to obtain the strong bonding between epoxy and fibers are takes place after etching. Among the various chemical treatments Epoxy(DER 383) treated fibers with epoxy are giving higher strength than other chemically treated fibers [9]. Hocheng et al investigates the effect of various types of drill bits. Majorly paper deals with the Thrust force for delamination. Among the various drills core drill having highest critical feed rate, twist drill having lowest feed rate for the lower delamination. The various drill bits like saw, step, candlestick drills can operate larger feed rate for without delamination [10]. Gaitonde et al describes to reduce delamination by controlling the process parameters on CFRP. The process parameters are cutting speed, feed rate, point angle respectively, twist drill can be used for drilling of composites. By using optimization using RSM technique approach they find the results. Optimized results by the High spindle speed, Lower feed rate and point angle reduces delamination of composites [11]. Hocheng et al describes a novel method is suitable for reduction of delamination in drilling by active backup force. The backup force contributes the reduction of the growth of the delamination of drilling exit by $60-80 \%$. The results shows at the lower delamination with the help of higher feed rate [12-14]. The aim of this study is to obtain the lower delamination in the prepared specimens with the appropriate tool.

\section{EXPERIMENTAL DETAILS}

\section{Specimen Details}

In the Specimen Preparation Kevlar 49 woven cloth fiber are chosen with polyester resin The Kevlar fiber mat and polymers are used to fabricate the KFRP plates with $6 \mathrm{~mm}$ thickness. The preparation of the composite by hand lay- up method. Before preparing the laminates woven are are chemically treated with dichloromethane, methanol.

\section{B. Chemical treatment for Fiber}

Usually the Chemical treatment will enhance the bonding strength between kevlar reinforced composite specimens. Aramid fibers are treated for 20 mins in dichloromethane then allowed to dry. Same procedure repeated with methanol and washed with distilled water. During the chemical treatment of the fibers, surface get repaired for bonding between matrix and reinforcement. This project an attempt made to reduce delamination during drilling by the treatment process.

\section{Preparation of Kevlar composite}

Hand lay-up technique is the simplest and oldest method for preparing composite materials. Preparation of reinforced composite specimen with chemically treated kevlar 49 cloth fiber and polyester resins with proportion of 60-40 ratio respectively on weight basis. Hand layup process used to make specimen. Compression moulding process is used for making a specimen for required thickness. In this project 15 layers are used for making $6 \mathrm{~mm}$ thickness of composite material. The treated and untreated specimens are shown in Fig.1. and Fig.2. below.

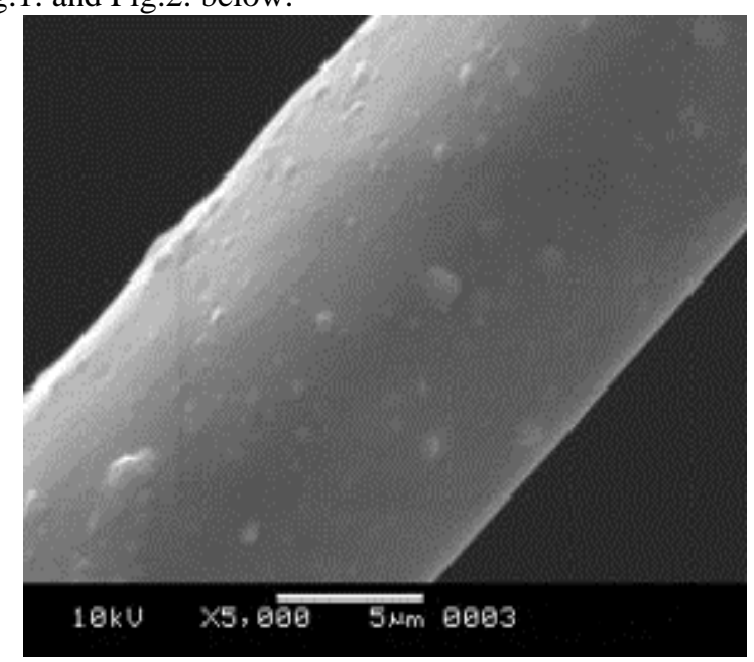

Fig.1. SEM image of treated specimen

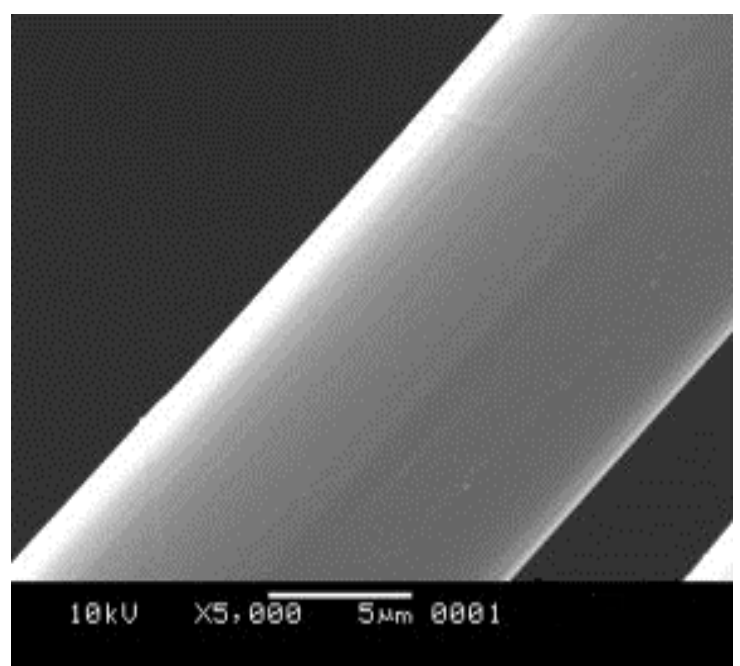

Fig.2. SEM image of untreated specimen 


\section{Drilling process setup}

The machining of Kevlar fiber composite was carried out in Vertical Machining Center, Makino S33 drilling machine with the help of dynamometer as shown in Fig.3.
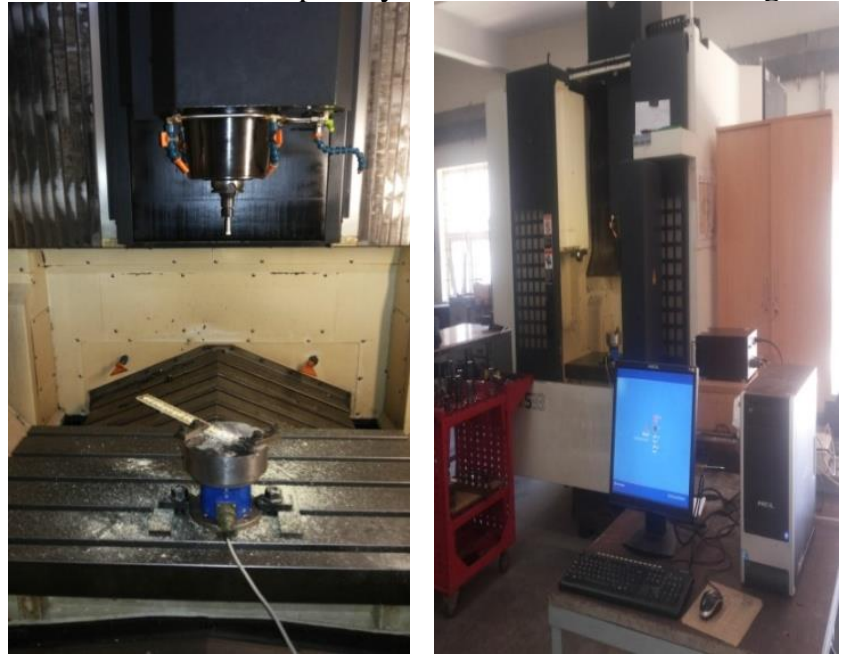

Fig.3. Setup for drilling KFRP Composites.

Process parameters chosen for drilling, the speed are 600rpm, 1000rpm and 1400rpm and feed rate are $45 \mathrm{~mm} / \mathrm{min}, 60 \mathrm{~mm} / \mathrm{min}$ and $75 \mathrm{~mm} / \mathrm{min}$. Drill tools are Twist and Core drill bits with $8 \mathrm{~mm}$ diameter. Polyester resin for making as specimen for $6 \mathrm{~mm}$ thickness. The drilling parameters are cutting speed and feed rate.

\section{RESULT AND DISCUSSION}

Kevlar fiber reinforced composite materials are used in aerospace industry, helmets, armours due to the high strength property. These composite laminates are joined by using various manufacturing process like drilling, milling, etc,. In this study we compared Twist drills and Core drills with $8 \mathrm{~mm}$ diameter. Drilling of composite is moreover different from the conventional process. In drilling of composite materials Delamination is the major cause of failure. The result are correlates with the selected parameters such as spindle speed and feed rate are considered as input during drilling operation, torque and Thrust force are obtained as output in Kevlar fiber reinforced composites. The selection parameters are shown in TABLE I.

Table I. Parameters For Drilling Kfrp Treated And Untreated Composites.

\begin{tabular}{|c|l|}
\hline \multicolumn{2}{|c|}{ DRILLING PARAMETERS } \\
\hline Feed rate mm/rev & $45,60,75$ \\
\hline Spindle speed rpm & $600,1000,1400$ \\
\hline Drill bit diameter mm & 8 \\
\hline Tool type & $\begin{array}{l}\text { Twist drill ,core } \\
\text { drill }\end{array}$ \\
\hline
\end{tabular}

From the various literature survey we identified Thrust force and torque are the major influence of delamination This project aimed to know the suitable parameters for lower delamination. Specimen preparations for this study are chemically treated specimen and untreated specimen.

Comparison of thrust force for chemically treated and untreated specimen drilled by twist drill bit as follows.
Table Ii. Thrust Force For A Chemically Treated Specimen Drilled By Twist Drill.

\begin{tabular}{|l|c|c|c|}
\hline Speed/Feed & $45 \mathrm{~mm} / \mathrm{min}$ & $60 \mathrm{~mm} / \mathrm{min}$ & $75 \mathrm{~mm} / \mathrm{min}$ \\
\hline $600 \mathrm{rpm}$ & 121 & 132 & 141 \\
\hline $1000 \mathrm{rpm}$ & 135 & 153 & 166 \\
\hline $1400 \mathrm{rpm}$ & 95 & 102 & 109 \\
\hline
\end{tabular}

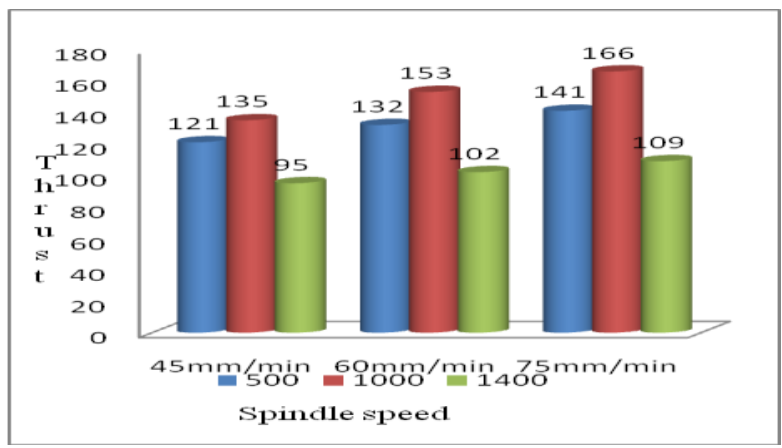

Fig.3. Thrust force for a chemically treated specimen drilled by twist drill

TABLE III. Thrust force for a chemically untreated specimen drilled by twist drill.

\begin{tabular}{|l|c|c|c|}
\hline Speed/Feed & $45 \mathrm{~mm} / \mathrm{min}$ & $60 \mathrm{~mm} / \mathrm{min}$ & $75 \mathrm{~mm} / \mathrm{min}$ \\
\hline $600 \mathrm{rpm}$ & 152 & 162 & 169 \\
\hline $1000 \mathrm{rpm}$ & 164 & 171 & 178 \\
\hline $1400 \mathrm{rpm}$ & 115 & 123 & 129 \\
\hline
\end{tabular}

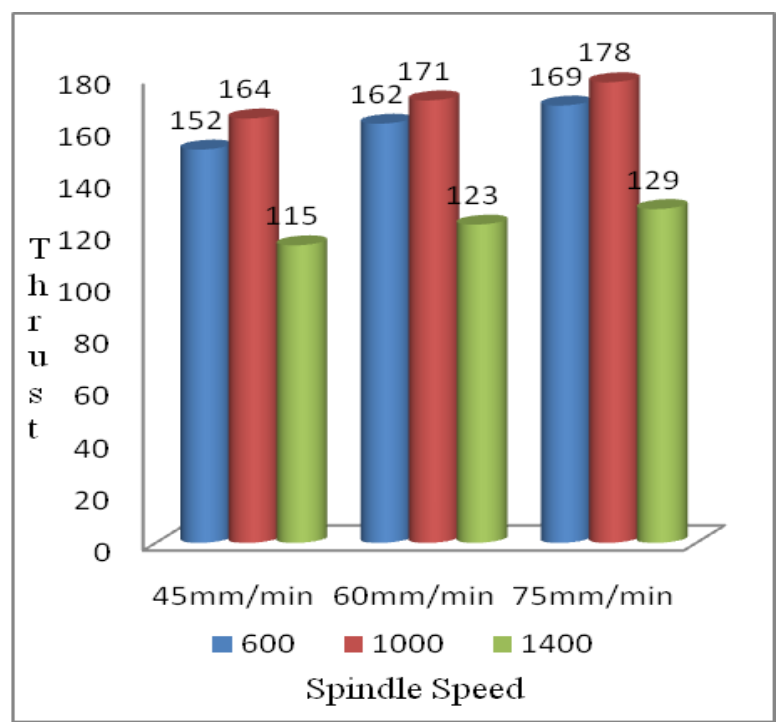

Fig.4. Thrust force for a chemically untreated specimen drilled by twist drill.

From the above graph results Fig. $3 \& 4$ shows variation between spindle speed and feed rate that the results shows for twist drill bit with the combination of treated and untreated specimens are as follows. 
Among the above results for a treated specimen maximum thrust are noted as $166 \mathrm{~N}$ at $1000 \mathrm{rpm}, 75 \mathrm{~mm} / \mathrm{min}$ and minimum as $95 \mathrm{~N}$ at $1400 \mathrm{rpm}, 45 \mathrm{~mm} / \mathrm{min}$.

Drilling operation for a untreated specimen by using twist drill shows the same above by considering the parametars. Minimum thrust force of $115 \mathrm{~N}$ obtained at $1400 \mathrm{rpm}$ and $45 \mathrm{~mm} / \mathrm{min}$.

The maximum thrust force of $178 \mathrm{~N}$ obtained at $1000 \mathrm{rpm}$ and $60 \mathrm{~mm} / \mathrm{min}$.

Figure 5. shows the obtained results of core drill bit by the following parameters such as spindle speed, feed rate and output result as thrust force. The treated specimen results concludes the maximum thrust shows as $551 \mathrm{~N}$ in the combination of lower speed and highest feed. For a high spindle speed and low feed shows as lower thrust force results as $223 \mathrm{~N}$.

Figure. 6 shows the following results for un treated specimen in the high speed and low feed rate as $241 \mathrm{~N}$ at $1400 \mathrm{rpm}$ and $45 \mathrm{~mm} / \mathrm{min}$. and also we notified as higher result of thrust force for these specimen as $571 \mathrm{~N}$ at $600 \mathrm{rpm}$ and $75 \mathrm{~mm} / \mathrm{min}$

Table Iv. Thrust Force For A Chemically Treated Specimen Drilled By Core Drill.

\begin{tabular}{|l|c|c|c|}
\hline Speed/Feed & $45 \mathrm{~mm} / \mathrm{min}$ & $60 \mathrm{~mm} / \mathrm{min}$ & $75 \mathrm{~mm} / \mathrm{min}$ \\
\hline $600 \mathrm{rpm}$ & 311 & 517 & 551 \\
\hline $1000 \mathrm{rpm}$ & 281 & 240 & 287 \\
\hline $1400 \mathrm{rpm}$ & 223 & 236 & 249 \\
\hline
\end{tabular}

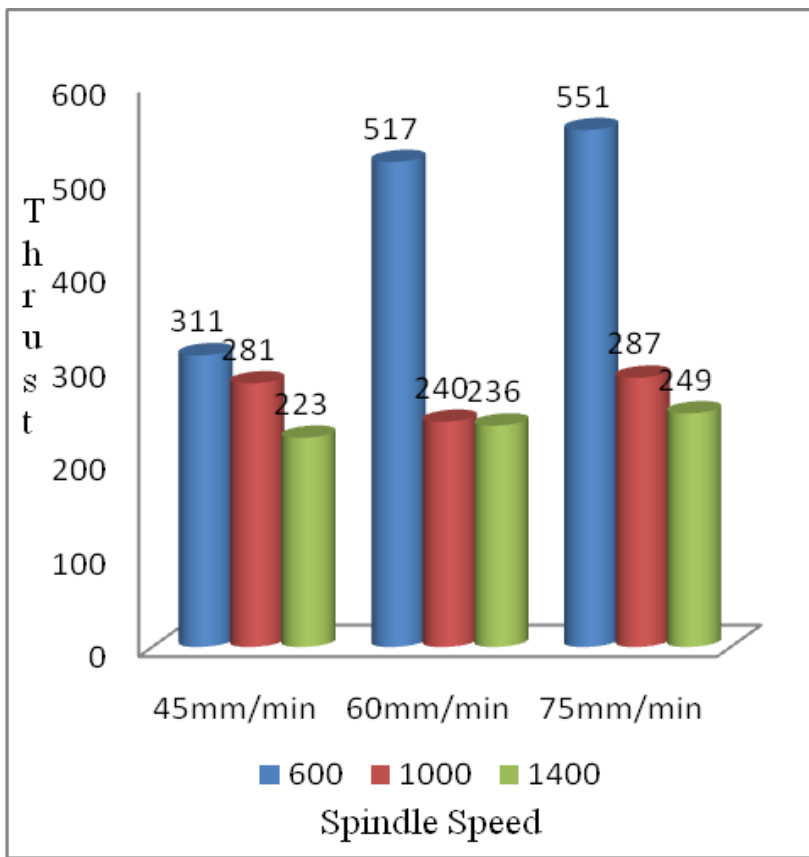

Fig.5. Thrust force for a chemically treated specimen drilled by core drill.

Table V. Thrust Force For A Chemically Untreated Specimen Drilled By Core Drill.

\begin{tabular}{|c|c|c|c|}
\hline Speed/Feed & $45 \mathrm{~mm} / \mathrm{min}$ & $60 \mathrm{~mm} / \mathrm{min}$ & $75 \mathrm{~mm} / \mathrm{min}$ \\
\hline $600 \mathrm{rpm}$ & 357 & 427 & 571 \\
\hline $1000 \mathrm{rpm}$ & 286 & 296 & 302 \\
\hline $1400 \mathrm{rpm}$ & 241 & 249 & 262 \\
\hline
\end{tabular}

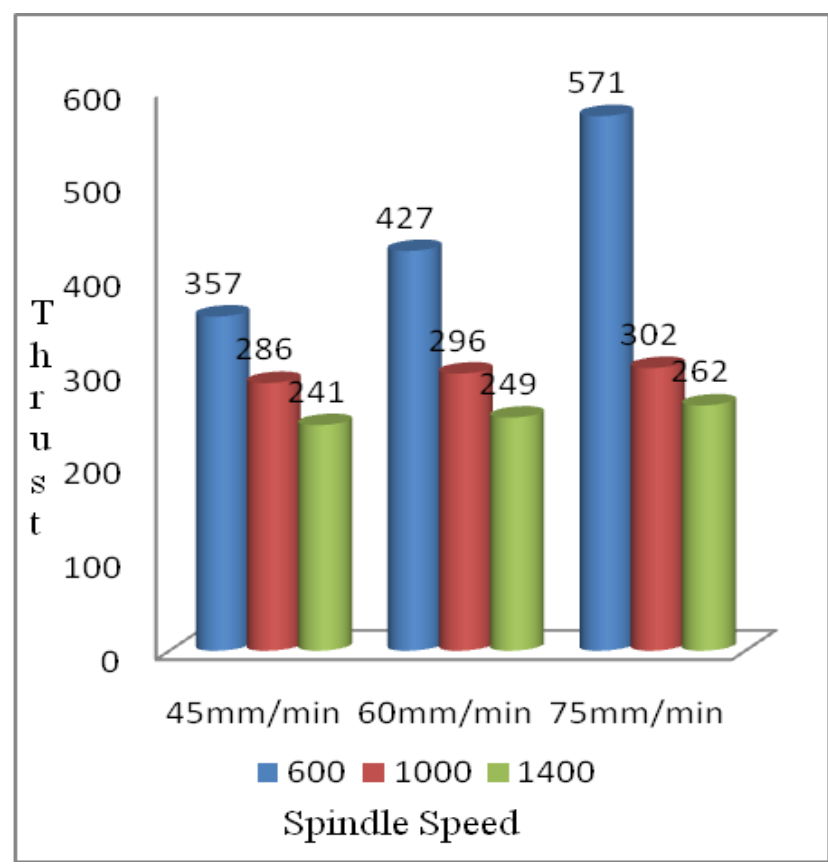

Fig.6. Thrust force for a chemically untreated specimen drilled by core drill.

Table Vi. Torque For A Chemically Treated Specimen Drilled By Twist Drill.

\begin{tabular}{|l|c|c|c|}
\hline Speed/Feed & $45 \mathrm{~mm} / \mathrm{min}$ & $60 \mathrm{~mm} / \mathrm{min}$ & $75 \mathrm{~mm} / \mathrm{min}$ \\
\hline $600 \mathrm{rpm}$ & 0.57 & 0.6 & 0.75 \\
\hline $1000 \mathrm{rpm}$ & 0.42 & 0.4 & 0.49 \\
\hline $1400 \mathrm{rpm}$ & 0.35 & 0.49 & 0.6 \\
\hline
\end{tabular}

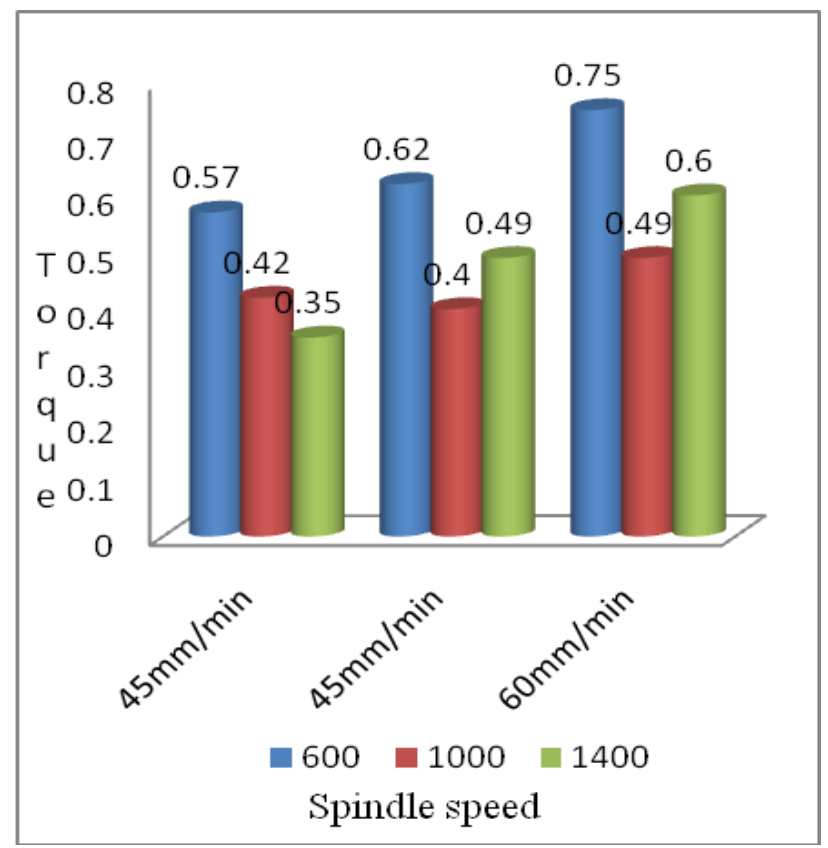

Fig.7. Torque for a chemically treated specimen drilled by Twist drill.

Published By:

Blue Eyes Intelligence Engineering

3104 \& Sciences Publication 
Figure.7 shows the results of Torque for twist drill with the following parameters such as Spindle speed and Feed rate. From the graph we conclude the highest and lowest torque for the specimens eith the help of $8 \mathrm{~mm}$ Twist drill maximum torque of treated specimen as $0.75 \mathrm{~N}-\mathrm{m}$ for $600 \mathrm{rpm}$ and $75 \mathrm{~mm} / \mathrm{min}$ as well as lowest torque are $0.35 \mathrm{~N}$ $\mathrm{m}$ at $45 \mathrm{~mm} / \mathrm{min}$ and $1400 \mathrm{rpm}$. Fig. 8 shows the results for untreated specimen as $0.74 \mathrm{~N}-\mathrm{m}$ for $75 \mathrm{~mm} / \mathrm{min}$ and $600 \mathrm{rpm}$ as a maximum and lower torque as $0.38 \mathrm{~N}-\mathrm{m}$.

Table Vii. Torque For A Chemically Untreated Specimen Drilled By Twist Drill.

\begin{tabular}{|l|c|c|c|}
\hline Speed/Feed & $45 \mathrm{~mm} / \mathrm{min}$ & $60 \mathrm{~mm} / \mathrm{min}$ & $75 \mathrm{~mm} / \mathrm{min}$ \\
\hline $600 \mathrm{rpm}$ & 0.63 & 0.69 & 0.74 \\
\hline $1000 \mathrm{rpm}$ & 0.48 & 0.45 & 0.51 \\
\hline $1400 \mathrm{rpm}$ & 0.38 & 0.41 & 0.43 \\
\hline
\end{tabular}

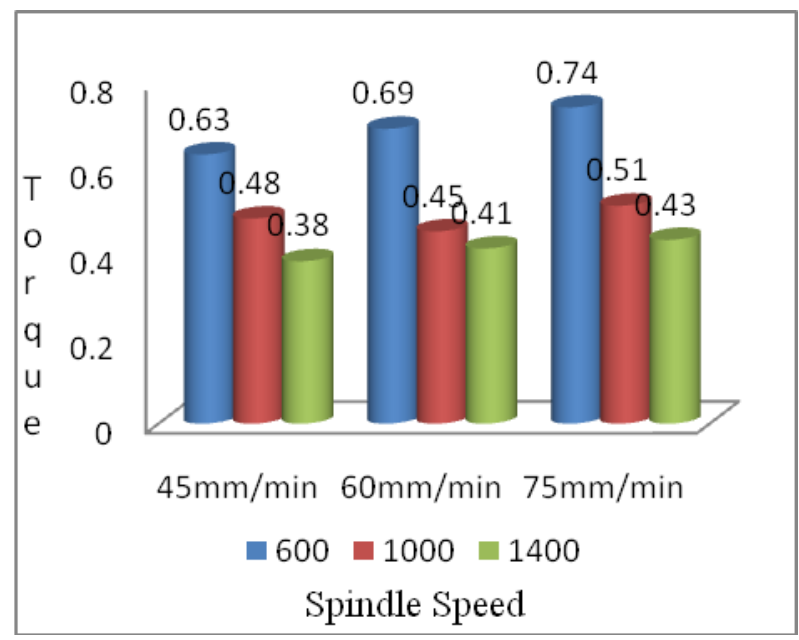

Fig.8. Torque for a chemically untreated specimen drilled by Twist drill.

From the Figure 9 and 10 shows the consideration of above parameters ,by changing the drill as Core drill of $8 \mathrm{~mm}$ shows the following maximum and minimum torque results as compared to various readings in the chart. The maximum torque for treated specimen for core drill is $0.98 \mathrm{~N}-\mathrm{m}$ at $75 \mathrm{~mm} / \mathrm{min}$ and $600 \mathrm{rpm}$ and for untreated specimen as $1.43 \mathrm{~N}-\mathrm{m}$ at $75 \mathrm{~mm} / \mathrm{min}$ and $600 \mathrm{rpm}$. The lowest torque as identified at high speed and low feed of treated and untreated specimen as $0.45 \mathrm{~N}-\mathrm{m}$ and $0.7 \mathrm{~N}-\mathrm{m}$ at $45 \mathrm{~mm} / \mathrm{min}$, 1400rpm.

Table Viii. Torque For A Chemically Treated Specimen Drilled By Core Drill.

\begin{tabular}{|l|c|c|c|}
\hline Speed/Feed & $45 \mathrm{~mm} / \mathrm{min}$ & $60 \mathrm{~mm} / \mathrm{min}$ & $75 \mathrm{~mm} / \mathrm{min}$ \\
\hline $600 \mathrm{rpm}$ & 0.74 & 0.89 & 0.98 \\
\hline $1000 \mathrm{rpm}$ & 0.53 & 0.67 & 0.79 \\
\hline $1400 \mathrm{rpm}$ & 0.45 & 0.56 & 0.64 \\
\hline
\end{tabular}

Fig.9. Torque for a chemically treated specimen drilled by core drill.

Table Ix. Torque For A Chemically Untreated Specimen Drilled By Core Drill.

\begin{tabular}{|l|c|c|c|}
\hline Speed/Feed & $45 \mathrm{~mm} / \mathrm{min}$ & $60 \mathrm{~mm} / \mathrm{min}$ & $75 \mathrm{~mm} / \mathrm{min}$ \\
\hline $600 \mathrm{rpm}$ & 1.02 & 1.21 & 1.43 \\
\hline $1000 \mathrm{rpm}$ & 0.84 & 0.92 & 0.99 \\
\hline $1400 \mathrm{rpm}$ & 0.7 & 0.85 & 0.91 \\
\hline
\end{tabular}

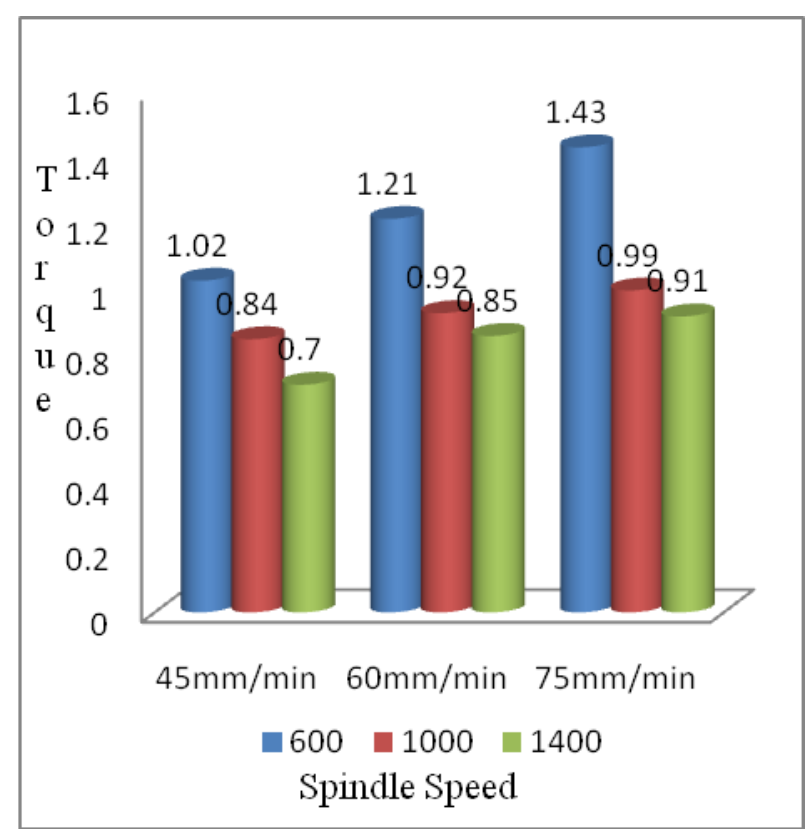

Fig.10. Torque for a chemically untreated specimen drilled by core drill.

\section{CONCLUSION}

Drilling influences the major damage in polymer-matrix composites in the form of delamination. Various Practical approaches have been carried out to minimize the damage occurred during drilling. 
In this study, the drilling operation has been done in the chemically treated Kevlar fiber reinforced composites to determine the lower delamination under various machining conditions. The above experimental results are shown the various results of thrust force and torque under various considered drilling parameters such as spindle speed, drilling feed rate and $8 \mathrm{~mm}$ diameter of twist and core drills. Based on the above experiment results the lower thrust force is identified at lower feed rate and high speed of the drill bit. Both treated and untreated Kevlar fiber reinforced composites are having thrust force. Similarly the torque is also identified for the both treated and untreated Kevlar fiber reinforced composites. The results exposed about the torque developed during the drilling operation by using the $8 \mathrm{~mm}$ diameter twist and core drill bits. The optimum torque is found that the low feed rate and high spindle speed.

In these investigation study we obtain two various results based on the types of drill bits. From that result Twist drill is suitable to drill the Kevlar fiber reinforced composites, because it reflects the lower torque and lower thrust force based up on the input of high spindle speed and low feed rate for the minimum delamination effect as compared to core drill.

\section{REFERENCES}

1. Srinivasan.T, Palanikumar.K and Rajagopal.K "Influence of thrust force in drilling of glass fiber reinforced polycarbonate thermoplastic composites using Box-Behnken Design" Information Conferences of Advances in Manufacturing and Materials Engineering, 2014, pp.2152-2158.

2. D. Bhattacharyya, and D. P. W. Horrigan, "A Study of Hole Drilling in Kevlar Composites," Composrfes Science and Tecbnofogy, 1998, Vol. 58, pp. 267-283.

3. N. Shuaib, F. A. Al-Sulaiman, and F. Hamid, "Machinability of Kevlar_ 49 Composite Laminates While Using Standard TiN Coated HSS Drills," MACHINING SCIENCE AND TECHNOLOGY, 2004, vol. 8, pp. 449-467.

4. Haijin Wang, Jie Sun, Jianfeng Li, and Weidong Li, "Investigation on delamination morphology during drilling composite laminates", Int J Adv Manuf Technol, 2014.

5. T.V. Rajamurugan, K. Shanmugam, and K. Palanikumar, "Analysis of delamination in drilling glass fiber reinforced polyester composites," Materials and Design, 2013, vol. 45, pp. 80-87.

6. C.C. Tsao, and H. Hocheng, "Evaluation of thrust force and surface roughness in drilling composite material using Taguchi analysis and neural network," Journal of materials processing technology, 2008 vol. 203, pp. 342-348.

7. C.C. Tsao, and H. Hocheng, "Effects of exit back-up on delamination in drilling composite materials using a saw drill and a core drill," International Journal of Machine Tools \& Manufacture, 2005, vol. 45 pp. 1261-1270.

8. S. R. WU, and C. S. SHEU, and S. S. SHYU, "Kevlar Fiber-Epoxy Adhesion and Its Effect on Composite Mechanical and Fracture Properties by Plasma and Chemical Treatment," Journal of Applied Polymer Science, 1996, vol. 62, pp. 1347-1360.

9. M.Takayanagi, S.Ueta, W.-Y. Lei, and K.Koga, "A New chemical method of Surface- treatment of Kevlar fiber for composites with Epoxy resin," Polymer Journal, 1987, Vol. 19, pp. 467-474.

10. H. Hocheng, and C.C. Tsao, "Effects of special drill bits on drillinginduced delamination of composite materials," International Journal of Machine Tools \& Manufacture , 2006, vol. 46 pp. 14031416.

11. V.N. Gaitonde, S.R. Karnik, J. Campos Rubio, A. Esteves Correia, A.M. Abrao, and J. Paulo Davim, "Analysis of parametric influence on delamination in high-speed drilling of carbon fiber reinforced plastic composites," Journal of materials processing technology, 2008, vol. 203 pp. 431-438.

12. C.C. Tsao, H. Hocheng, and Y.C. Chen, "Delamination reduction in drilling composite materials by active backup force," Manufacturing Technology, 2012, vol. 61 pp. 91-94.

13. K.Periasamy, N.Sivashankar, S.Chandrakumar, R.Viswanathan, "Measurement of Friction and Wear in Aluminum Alloy A17075/Sic \& Gr Processed By Friction Stir Method" International Journal of
Innovative Technology and Exploring Engineering, 2020, Vol 9 , pp.278-281.

14. Viswanathan R, Sivashankar N, Chandrakumar S and Karthik R, 'Improving Corrosion Resistance of Magnesium Alloy for Aerospace Applications' International Journal of Mechanical and Production Engineering Research and Development, 2019, Volume 9, pp.769-774.

\section{AUTHORS PROFILE}

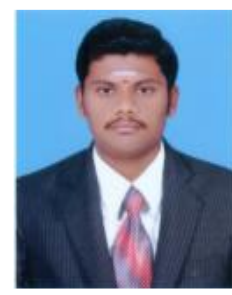

Mr. S. Chandrakumar.M.E., Assistant Professor, Dept. of Mech. Engg., Kongunadu College of Engg. \& Tech, Tamil Nadu. He has completed his Master of Engineering "Engineering Design" in Kongu Engineering College (Autonomous) affiliated to Anna University, Chennai. His special areas of interest are metal matrix composites and optimization techniques. He published five research papers in various journals and conferences.

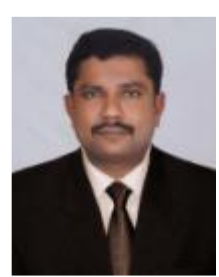

Dr. K. Periasamy,He is an Professor and coordinator in Mechanical Engineering at Kongunadu College of Engg. and Tech. Trichy, Tamilnadu, India. He has more than 14 years of experience in Engineering colleges in Tamilnadu, India. He has completed his under graduation in Mechanical Engineering in 1999 from Madras University and post-graduation in Manufacturing Engineering in 2010 from VMKV Engineering College, India. He received his $\mathrm{PhD}$ (Mechanical Engineering) from Anna University Chennai, India. His specialization and research are material science and friction stir processing.

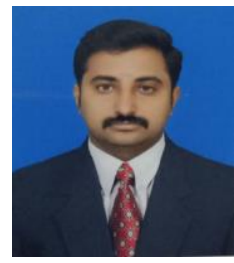

Mr. N. Sivashankar.M.E.(Ph.D), Assistan Professor, Dept. of Mech. Engg., Kongunadu College of Engg. \& Tech, Tamil Nadu. He has completed his Master of Engineering "Engineering Design" with Distinction in PGP College of Engineering and Technology, Affiliated to Anna University, Chennai. His special areas of interest are Machining of aerospace alloy, composite materials and optimization techniques. He published six research papers in various journals and conferences.

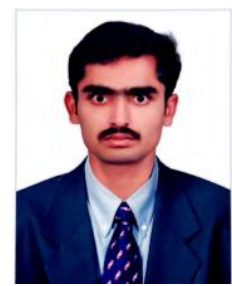

Mr. V. Vairamani.M.E, Assistant Professor, Dept of Mech. Engg., Kongunadu College of Engg. \& Tech, Tamil Nadu. He has completed his Master of Engineering "Welding Techology" in Government college of Engineering Salem. His special areas of interest are Machining and Welding technology. He published six research papers in various journals and conferences. 